\title{
A closer look at presynaptic $\mathrm{GABA}_{\mathrm{B}}$ receptors
}

The probability of neurotransmitter release, which is a key determinant of synaptic strength, shows considerable heterogeneity between synapses, but the origin of such variability is unclear. $\mathrm{GABA}_{\mathrm{B}}(\gamma$-aminobutyric acid type $B$ ) receptors are located presynaptically on glutamatergic hippocampal boutons and are known to negatively regulate release probability. Previous studies on $\mathrm{GABA}_{B}$ receptors were undertaken on synapse populations, and so were unable to characterize their regulation by local conditions. Now, studying individual synaptic boutons, Laviv et al. show a role for this receptor in the variability in release probability and in the homeostatic regulation of hippocampal circuits.

$\mathrm{GABA}_{\mathrm{B}}$ receptors are heterodimers, consisting of a GB1 and a GB2 subunit. To investigate whether the receptors are activated in the absence of neuronal firing, the authors blocked spike-dependent activity with tetrodotoxin and measured GB1-GB2 dimerization through fluorescence resonance energy transfer (FRET) between fluorescently tagged subunits. They showed that receptor dimerization occurred under such basal conditions, and to a variable degree at individual boutons along a single axon.

The intersynapse variability was not observed at non-functional boutons lacking synaptic vesicle release, suggesting that it is not an intrinsic property of the $\mathrm{GABA}_{\mathrm{B}}$ receptor. Conversely, heterogeneity of the FRET signal was reduced by pharmacologically inhibiting the $\mathrm{GABA}_{\mathrm{B}}$ receptor or by maximally activating the receptor with a saturating dose of the $\mathrm{GABA}_{\mathrm{B}}$ agonist baclofen. Local variations in GABA levels therefore seem to underlie the heterogeneity of $\mathrm{GABA}_{\mathrm{B}}$ receptor activation across hippocampal boutons.

Next, the authors undertook the ambitious approach of integrated FM dye-based tracking, which indicates presynaptic vesicle turnover, with FRET imaging. They showed that $\mathrm{GABA}_{\mathrm{B}}$ receptor dimerization is inversely correlated with the probability of glutamate release at individual synapses, both at rest and under $1-\mathrm{Hz}$ field stimulation to the same population of boutons.

The authors sought to determine whether the $\mathrm{GABA}_{\mathrm{B}}$ receptor plays a part in long-term adaptation of synaptic connections to prolonged neuronal inactivity. Pharmacological blockade of neurotransmission for 48 hours reduced the FRET signal between GB1 and GB2 and increased the probability of vesicle release, suggesting a homeostatic mechanism to counteract the reduced synaptic transmission. Prolonged inactivity affected neither the properties of $\mathrm{GABA}_{\mathrm{B}}$ receptors nor GABA clearance, suggesting that the presynaptic enhancement was caused by a reduction in basal GABA levels. Thus, regulation of basal $\mathrm{GABA}_{\mathrm{B}}$ receptor activity may play a part in synaptic homeostasis in response to changes in ongoing neuronal activity.

Finally, the authors compared the influence of the $\mathrm{GABA}_{\mathrm{B}}$ receptor at various points along the dendritic tree. They found that $\mathrm{GABA}_{\mathrm{B}}$ tone was higher at thick, proximal dendrites than at short, distal ones, and proposed that this may arise from the more highly innervated nature of proximal branches, which would lead to shorter diffusion distances for GABA from the site of release to presynaptic excitatory boutons.

Together, these studies shed light on presynaptic regulation by $\mathrm{GABA}_{\mathrm{B}}$ receptors that has important implications for the modulation of synaptic strength in the hippocampus and hence for learning and memory. Sian Lewis

ORIGINAL RESEARCH PAPER Laviv, T. et al. Basal GABA regulates $\mathrm{GABA}_{\mathrm{B}} \mathrm{R}$ conformation and release probability at single hippocampal synapses. Neuron 67, 253-267 (2010)

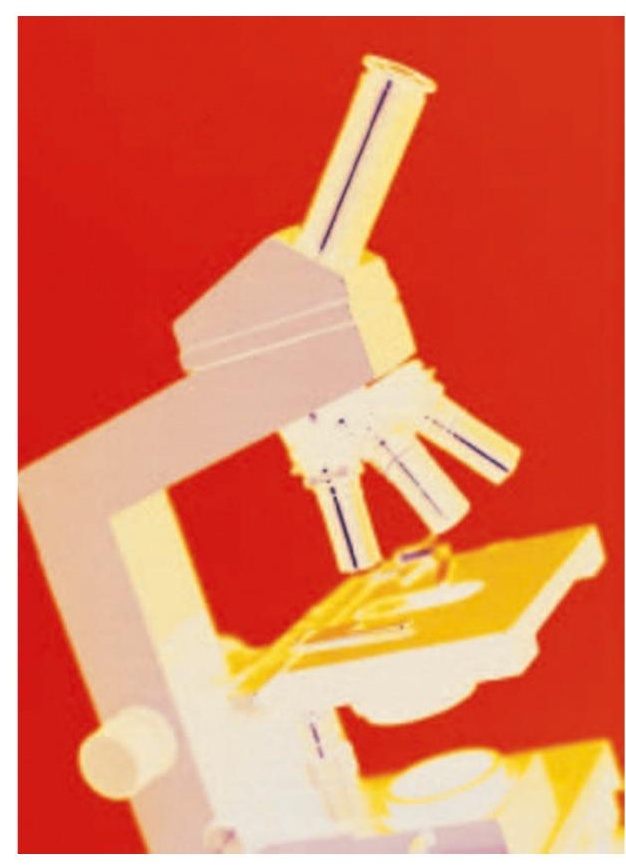

